\title{
Foeto-maternal Outcome in Scarred and Unscarred Rupture Uterus of North Indian Population
}

\author{
Meenakshi Singh ${ }^{1}$, Pushplata Sachan², Munna Lal Patel ${ }^{3}$, Rekha Sachan ${ }^{1, *}$
}

\section{Meenakshi Singh ${ }^{1}$, Push- plata Sachan², Munna Lal Patel $^{3}$, Rekha Sachan ${ }^{1, *}$}

'Department of Obstetrics and Gynaecology, King George Medical University, Lucknow, Uttar Pradesh, INDIA. ${ }^{2}$ Department of Physiology, Career Institute of Medical Sciences, Lucknow, Uttar Pradesh, INDIA.

${ }^{3}$ Department of Medicine, King George Medical University, Lucknow, Uttar Pradesh, INDIA.

\section{Correspondence}

Prof. Rekha Sachan,

(MS, FICOG), Professor, Department of Obstetrics and Gynaecology, King George Medical University, Lucknow Uttar Pradesh-226003, INDIA. Mobile no: +91-8765000700

Email: drrekhasachan@gmail.com

History

- Submission Date: 29-07-18

- Revised Date: 16-11-18

- Accepted Date: 04-03-19

DOI : 10.5530/ijmedph.2019.2.12

Article Available online

http://www.ijmedph.org/v9/i2

\section{Copyright}

(C) 2019 Phcog.Net. This is an openaccess article distributed under the terms of the Creative Commons Attribution 4.0 International license.

\begin{abstract}
Background: Uterine rupture is a rare devastating obstetrical complication that endanger the women life. Objective: To compare the risk factors, complications, foetal and maternal outcome in cases of uterine rupture either unscarred or scarred uterus. Material and Methods: Retrospective study was carried out in Department of Obstetrics and Gynaecology at tertiary teaching hospital, Records of all pregnant women who were admitted for delivery during a follow up period of January 2015 to June 2016, data were collected from hospitals records and analyzed. A total of 96 patients were identified with rupture uterus and only 92 women records were analyzed because 4 women died before any intervention. On the basis of records these 92 cases of rupture uterus further categorized into two groups, group one consisted of unscarred rupture uterus and group two were comprised of scarred uterus with dehiscence. Results: Rupture uterus was found in $0.74 \%$ pregnant women in our study. $52.2 \%$ (48) rupture uterus was found in unscarred uterus and $47.8 \%(44)$ in scarred uterus. $70.8 \%$ (34) rupture was found at term pregnancy in unscarred uterus and $63.6 \%$ (28) in scarred uterus. Complete rupture was more common in unscarred uterus $95.8 \%(46)$ as compared to scarred uterus $36(81.8 \%)$. Incomplete rupture was found more in scarred uterus $8(18.1 \%)$ in comparison to unscarred uterus $2(4.1 \%)(p<0.044)$. Uterus repair with bilateral tubal ligation was performed more in scarred $25 \%(11)$ as compared to unscarred uterus $4(8.3 \%)(p<0.047)$. Total maternal deaths were $9.37 \%$ (9) but 4 died un investigated. Perinatal deaths were $91.30 \%$ (84). Conclusion: Morbidity is high with unscarred rupture as compared to rupture of scarred uterus, more hysterectomies performed in unscarred rupture due to involvement of both segment of uterus.
\end{abstract}

Key words: Uterine rupture, Caesarean section, Hysterectomy, Hemorrhagic shock.

\section{INTRODUCTION}

Uterine rupture is defined as a full-thickness separation of all the layers of uterine wall including overlying serosa. The tear could be present on anterior, posterior, or lateral wall of uterus or combination of these. Uterine rupture is typically classified as either complete or incomplete.

Complete uterine rupture, when all layers of the uterine wall are separated and incomplete rupture or scar dehiscence means uterine wall is separated but the visceral peritoneum is intact.

Risk factors for uterine rupture included grand multiparty, malpresentation, prolonged labour, obstructed labour, uterine anomaly, instrumental deliveries, delivery by unskilled personnel, use of over doses of oxytocin and prostaglandins for induction of labour, Previous uterine surgery (Myomectomy and caesarean section), foetal macrosomia. ${ }^{1}$ Nowadays caesarean section is an important risk factor responsible for rupture uterus all over the world. ${ }^{2,3}$ Uterine rupture is a clinical diagnosis and there must be a high index of suspicion by clinician because of variable presentation. Most Women presented with maternal tachycardia, hypovolemic shock, history of constant abdominal pain followed by cessation of uterine contractions, loss of foetal station, uterine tenderness and change in uterine contour and slight vaginal bleeding. The most consistent early indicator of uterine rupture is the onset of a prolonged, persistent foetal bradycardia but there is no foetal heart rate pattern pathognomonic of rupture. ${ }^{4-6}$

Aim of this study was to compare the risk factors, complications, foetal and maternal outcome in cases of uterine rupture either unscarred or scarred uterus.

\section{MATERIAL AND METHODS}

This retrospective study was carried out in the Department of Obstetrics and Gynaecology, at tertiary care hospital, North India. After ethical clearance records of all pregnant women who were admitted for delivery during a period of January 2015 to June 2016, data were collected from hospitals records and analyzed. A total of 96 patient's records had been identified with rupture uterus and we had analyzed in detail only 92 women records because 4 women died before any interventions.

As per records these patients who had rupture of uterus either in our hospital or referred from other hospi-
Cite this article : Singh M, Sachan P, Patel ML, Sachan R. Foeto-maternal Outcome in Scarred and Unscarred Rupture Uterus of North Indian Population. Int J Med Public Health. 2019;9(2):46-9. 
tals were divided into two groups on the basis of previous surgeries over the uterus : Group A included unscarred 'uterus without any previous history of uterine surgery while Group B consist of scarred uterus with history of one or more previous caesarean section, uterine curettage, previous myomectomy or uterine rupture repair. Both groups were compared for parameters like maternal age, parity, risk factor, site of rupture, operative procedures, foetal outcome, maternal morbidity and mortality.

Every women with rupture uterus received emergency obstetric care first then planned for surgery. Surgical management was performed as repair of uterus with bilateral tubal ligation, repair of uterus without tubal ligation and hysterectomy either total or subtotal.

\section{Statistical Analysis}

The data was collected on predetermined questionnaire from hospital records and analysis was done by using descriptive statistics and frequency with percentages. For group comparison student t-test and chi- square test was used. $p$-value $<0.5$ considered significant.

\section{RESULTS}

Rupture uterus were identified in 96 cases out of 12,960 admission of pregnant women for delivery during a follow up, thus the rupture of uterus was reported $0.74 \%$ in this study.

In present study out of 92 cases of rupture uterus, $52.2 \%$ (48) unscarred uterus underwent rupture and $47.8 \%$ (44) had rupture of scarred uterus. Here maximum rupture were reported within age group of 26 to 30 year, unscarred uterus rupture found in $54.2 \%$ (26) and scarred uterus rupture in $52.2 \%$ (23) at this age group. Overall maximum rupture uterus was observed at term gestation age. Uterine rupture at $>37$ weeks of gestation, present in $70.8 \%$ (34) cases of unscarred uterus and 63.6\% (28) in scarred uterus. Both groups did not differ significantly in the terms of age, antenatal booking status, history of curettage. There were significant difference in terms of parity and it was also observed that rupture of uterus mainly happened in unbooked and unsupervised deliveries. Rupture of unscarred uterus more common in grand multiparous women (parity $>5$ ) whereas scarred uterine rupture commonly found with parity 1 to $2(p<0.001)$. (Table 1$)$.

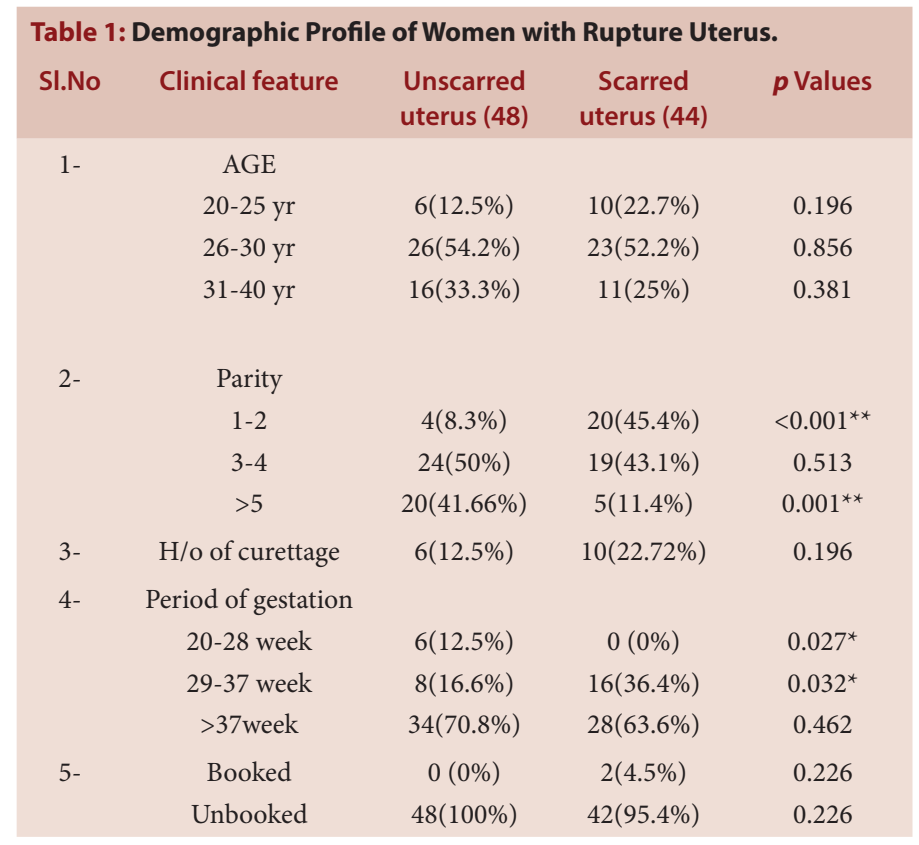

In present study common causes of uterine rupture in unscarred uterus were obstructed labour $31.5 \%$ (29) and multiparity $16.3 \%$ (16) whereas previous caesarean section was the most common risk factor $45.6 \%$ (42) for dehiscence of scarred uterus. (Figure 1)

Complete uterine rupture was more common in unscarred uterus 46 (95.8\%) as compared to scarred uterus $36(81.8 \%)$ while incomplete uterine rupture was detected more in scarred uterus $8(18.1 \%)$ as compared to unscarred uterus $2(4.1 \%)$ and results were statistically significant $(p<0.044)$. Lower segment rupture was found more in scarred uterus 22 $(50 \%)$ as compared to unscarred uterus 15 (31.2\%). After laparatomy records, evaluation both upper and lower segment involvement was observed in $58.3 \%$ of unscarred uterus and in $31.8 \%$ of scarred uterus $(p<0.011)$ Vagina and broad ligament involvement was found more in unscarred uterus rupture as compared to involvement of bladder this might be because of high intrauterine pressure. While cervix and bladder involvement was more commonly found in scarred uterus might be because of passive dehiscence of previous scar. (Table 2)

Total and subtotal abdominal hysterectomies were performed more in unscarred uterus as compared to scarred uterus, this might be because of complete rupture often involve cervix and vagina or extension in broad ligament, making difficult to repair. Uterus repair with ligation was performed more in scarred uterus $11(25 \%)$ as compared to unscarred uterus $4(8.3 \%)$ and this difference was statistically significant $(p<0.047)$. Requirement of bladder repair was more with scarred uterus 4 (9\%) along with hysterectomy while with unscarred rupture uterus repair in less cases, only $4.1 \%$ (2) required bladder repair. Out of 96 women with rupture uterus total $9(9.37 \%)$ maternal deaths were reported in both the groups. Out of 9 deceased, 4 women expired uninvestigated and 5 (5.43\%) women expired after surgery. These 5 (5.4\%) deaths were mainly due to hemorrhagic shock and septicaemia. Blood was transfused in each and every women either during intra-operative or postoperative period. Maximum women required three to four-unit packed red cells in both the group, group 1 and 2, in $70.8 \%$ and 59.1\% respectively. Requirement of Fresh frozen plasma transfusion was $54.2 \%$ and 22 (50\%) in women with rupture of unscarred and scarred uterus respectively.

Maximum women were discharged in satisfactory condition after this catastrophic event within eight to ten days, $58.3 \%$ (28) and $86.4 \%$ (38)

\begin{tabular}{|c|c|c|c|c|}
\hline $\begin{array}{l}\text { SI. } \\
\text { No }\end{array}$ & Site & $\begin{array}{c}\text { Unscarred } \\
\text { uterus } \\
\text { (48) }\end{array}$ & $\begin{array}{l}\text { Scarred } \\
\text { uterus } \\
\text { (44) }\end{array}$ & $p$ value \\
\hline \multirow[t]{3}{*}{$1-$} & \multicolumn{4}{|c|}{ Type of rupture } \\
\hline & Complete rupture & $46(95.8 \%)$ & $36(81.8 \%)$ & \\
\hline & Incomplete rupture & $2(4.1 \%)$ & $8(18.1 \%)$ & $0.044^{*}$ \\
\hline \multirow[t]{4}{*}{$2-$} & \multicolumn{4}{|c|}{ Site of rupture } \\
\hline & upper segment rupture & $5(10.4 \%)$ & $8(18.1 \%)$ & 0.286 \\
\hline & lower segment rupture & $15(31.2 \%)$ & $22(50 \%)$ & 0.067 \\
\hline & Both US+LS rupture & $28(58.3 \%)$ & $14(31.8 \%)$ & $0.011^{\star}$ \\
\hline \multirow[t]{6}{*}{$3-$} & \multicolumn{4}{|c|}{ Involvement of nearest organ } \\
\hline & No injury & $32(66.8 \%)$ & $29(65.9 \%)$ & $0.002^{* *}$ \\
\hline & Cervix & $2(4.1 \%)$ & $3(6.8 \%)$ & 0.667 \\
\hline & Vagina & $5(10.4 \%)$ & $4(9 \%)$ & 1.000 \\
\hline & Broad ligament & $5(10.4 \%)$ & $3(6.8 \%)$ & 0.716 \\
\hline & Bladder involvement & $4(8.3 \%)$ & $5(11.4 \%)$ & 0.732 \\
\hline
\end{tabular}




\begin{tabular}{|c|c|c|c|}
\hline Clinical Feature & $\begin{array}{l}\text { Unscarred } \\
\text { uterus (48) }\end{array}$ & $\begin{array}{l}\text { Scarred } \\
\text { uterus (44) }\end{array}$ & $p$ value \\
\hline Uterus Repair & $16(33.3 \%)$ & $13(29.5 \%)$ & 0.696 \\
\hline Uterus repair with ligation & $4(8.3 \%)$ & $11(25 \%)$ & $0.047^{*}$ \\
\hline \multicolumn{4}{|l|}{ Hysterectomy } \\
\hline Total abdominal hysterectomy & $23(47.9 \%)$ & $17(38.6 \%)$ & 0.370 \\
\hline \multicolumn{4}{|l|}{ Subtotal hysterectomy } \\
\hline & $5(10.4 \%)$ & $3(6.8 \%)$ & 0.716 \\
\hline \multicolumn{4}{|l|}{ Other structure involvement } \\
\hline Bladder repair & $2(4.1 \%)$ & $4(9 \%)$ & 0.421 \\
\hline Iontropic support & $12(25 \%)$ & $10(22.7 \%)$ & 0.799 \\
\hline Ventillatory support & $18(37.5 \%)$ & $12(27.3 \%)$ & 0.296 \\
\hline Mortality & $3(6.8 \%)$ & $2(4.7 \%)$ & 1.000 \\
\hline $\begin{array}{l}\text { Duration in ventilatory unit. } \\
\text { (days) }\end{array}$ & $14(29.2 \%)$ & $10(22.7 \%)$ & 0.482 \\
\hline Total hospital stay & $28(58.3 \%)$ & $38(86.4 \%)$ & \\
\hline $8-10$ & $20(41.7 \%)$ & $6(13.4 \%)$ & $0.003^{* *}$ \\
\hline \multicolumn{4}{|l|}{$>14$ days } \\
\hline Blood transfusion & 48 & 44 & \\
\hline One-unit PRBC & $3(6.3 \%)$ & $4(9.1 \%)$ & 0.706 \\
\hline Two-unit PRBC & $11(22.9 \%)$ & $14(31.8 \%)$ & 0.338 \\
\hline Three to four-unit PRBC & $34(70.8 \%)$ & $26(59.1 \%)$ & 0.238 \\
\hline Fresh frozen plasma & $26(54.2 \%)$ & $22(50 \%)$ & 0.689 \\
\hline
\end{tabular}

Risk factors T-92

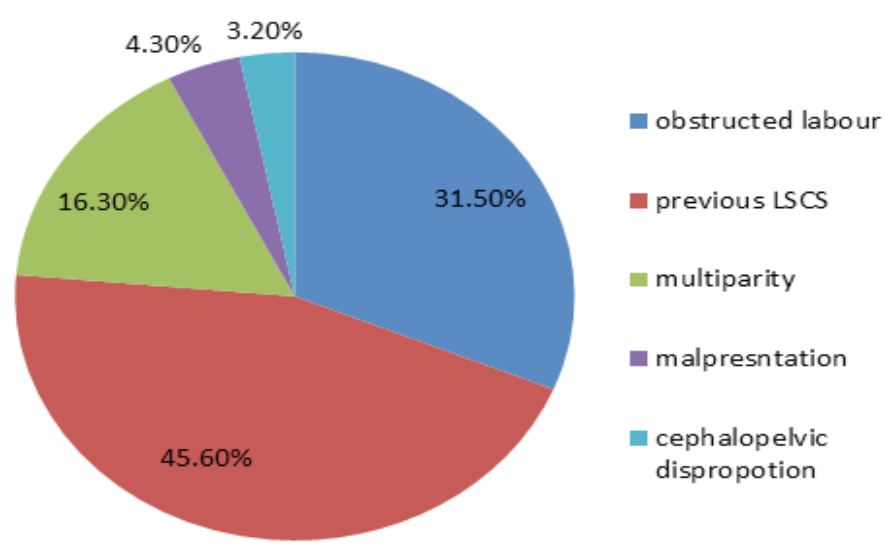

Figure 1: Risk Factors Responsible for Rupture Uterus.

in unscarred and scarred rupture group respectively. Requirement of Prolonged hospital stay more in unscarred uterus rupture $20(41.7 \%)$ as compared to scarred uterus rupture $6(13.4 \%)$ and this difference was statistically significant $(p<0.003)$. (Table 3 ) Perinatal mortality was $91.30 \%$ in present study. Total Perinatal deaths 84 out of total92 cases of rupture uterus. Almost half of the foetus died within the uterus, only 8 live babies were born from scarred uterus group whom incomplete scar dehiscence was detected during emergency caesarean section. These 8 women were admitted in emergency with acute foetal distress and scar tenderness thus suspicion of impending rupture arose. Live birth in scarred uterus rupture was high as compared to unscarred rupture $(p<0.002)$. Out of 8

\begin{tabular}{|c|c|c|c|c|}
\hline SI.No & Clinical feature & $\begin{array}{l}\text { Unscarred } \\
\text { uterus (48) }\end{array}$ & $\begin{array}{c}\text { Scarred } \\
\text { uterus (44) }\end{array}$ & $p$ value \\
\hline $1-$ & Live & $0(0 \%)$ & $8(18.1 \%)$ & $0.002^{* *}$ \\
\hline $2-$ & Still birth & $48(100 \%)$ & $36(81.8 \%)$ & 0.310 \\
\hline $3-$ & Neonatal intensive unit & $0(0 \%)$ & $3(6.8 \%)$ & 0.106 \\
\hline 4- & Neonatal death & $0(0 \%)$ & $2(4.5 \%)$ & 0.226 \\
\hline \multirow[t]{4}{*}{$5-$} & Birth weight of baby & & & \\
\hline & $<2.5 \mathrm{~kg}$ & $6(12.5 \%)$ & $8(18.1 \%)$ & $0.449^{*}$ \\
\hline & 2.5 to $3.5 \mathrm{~kg}$ & $25(52 \%)$ & $18(40.9 \%)$ & 0.283 \\
\hline & $>3.5$ & $17(35.4 \%)$ & $22(50 \%)$ & 0.157 \\
\hline
\end{tabular}

\begin{tabular}{cccc}
\multicolumn{2}{c}{ Table 5: Post-Operative Morbidity. } & & \\
$\begin{array}{c}\text { Maternal } \\
\text { morbidity/ } \\
\text { morbidity }\end{array}$ & $\begin{array}{c}\text { Unscarred } \\
\text { uterus (48) }\end{array}$ & $\begin{array}{c}\text { Scarred uterus } \\
\mathbf{( 4 4 )}\end{array}$ & $\boldsymbol{p}$ value \\
\hline Anaemia & $38(79.1 \%)$ & $31(70.5 \%)$ & 0.335 \\
Paralytic ileus & $3(6.3 \%)$ & $4(9.1 \%)$ & 0.706 \\
Surgical site infection & $2(4.1 \%)$ & $3(6.8 \%)$ & 0.667 \\
Fever & $5(10.41 \%)$ & $6(13.6 \%)$ & 0.635 \\
\hline
\end{tabular}

live born babies three neonates required neonatal intensive care and out of these two neonates died. (Table 4)

Anaemia was the common complication in women of both groups but it was more in unscarred rupture uterus $(79.1 \%)$ versus $70.5 \%$ in scarred uterine rupture, followed by paralytic ileum 3 (6.3\%) in unscarred versus $4(9.1 \%)$ in scarred rupture uterus. Surgical site infection found in $4.1 \%$ (2) and $3(6.8 \%)$ cases of unscarred versus scarred rupture uterus. No statistically significant difference was observed between both two groups in the terms of complication. (Table 5)

\section{DISCUSSION}

Uterine rupture is an uncommon devastating obstetrical emergency associated with significant maternal and perinatal morbidity and mortality. ${ }^{7}$ Usually it is more frequently associated with scarred uterus as compared to unscarred uterus. Maternal mortality is the worst complication of uterine rupture, it occurs in approximately1 in 500 uterine ruptures. ${ }^{8}$ According to $\mathrm{WHO}$ the incidence of rupture uterus in general population is 5.3/10,000 birth. ${ }^{9}$ In developing countries incidence of uterine rupture is far higher ( 1 in 106) ${ }^{10}$ as compared to the developed countries where it is approximately 74 in $10,000 .{ }^{11}$ Rupture of an unscarred uterus is a rare event involving 1:17,000-20,000 deliveries. ${ }^{12}$ In present study incidence of uterine rupture was $0.74 \%$, while study done by other authors reported incidence of rupture, $0.038 \%$ and $0.057 \% .^{13,14}$ This high incidence might be due to increased caesarean section and our institute is largest referral centre of northern India. In our study all women were unbooked (100\%) and had not received any antenatal care during pregnancy similarly other studies reported $80 \%$ and $78.68 \%$ women were unbooked in their study. ${ }^{15,7}$

Here rupture commonly found in 26 to 30 years of age group and next common age group was 31 to 40 year similarly another study reported 
Singh, et al.: Foeto-maternal Outcome in Uterine Rupture

increasing maternal age has detrimental effect on uterine rupture. ${ }^{16}$ In present study among unscarred group 50\% rupture were found within parity of 3 to 4 followed by $41.66 \%$ with parity $>5$, whereas maximum cases $43.1 \%$ rupture in scarred uterus group found within the parity of 3 to 4 , similarly another studies also reported multiparity is a very important predisposing factor which was found in $97.9 \%$ of cases. ${ }^{17}$ One study reported $32 \%$ unscarred uterine rupture had a parity of 4 and more. ${ }^{18}$

In present study common causes of unscarred uterine rupture were obstructed labour in $31.5 \%$ and multiparity in $16.3 \%$, cephalopelvic disproportion $3.20 \%$ whereas previous caesarean section was the most common risk factor in $45.6 \%$ for scarred uterine rupture. In contrast study done by other author common causes of rupture uterus were Pitocin induced labour in $51.6 \%$, great multiparty in $42.2 \%$, Previous uterine scar in $18.8 \%$ and obstructed labour in $12.5 \% .{ }^{19}$ Another studies reported common causes of rupture uterus were great multiparty in $41.5 \%$, Pitocin induced labour in 58.5\%, malpresentation and malposition in $12.1 \%$ and CPD 9.8\%. ${ }^{20,21}$

One study reported $19.2 \%$ association of previous caesarean section with rupture uterus. ${ }^{22}$ In present study $52.2 \%$ in unscarred group and $47.8 \%$ in scarred group had uterine rupture similarly one study reported higher incidence $85.3 \%$ unscarred rupture while rupture in scarred uterus $14.7 \%$ were found with previous scar. ${ }^{23}$ Hysterectomy performed in present study, in $47.9 \%$ cases of unscarred rupture while in $38.6 \%$ scarred rupture uterus and study done by another authors reported hysterectomies in $34.86 \%$ unscarred rupture and in 35\% scarred rupture uterus. ${ }^{24,25}$ In present study lower uterine segment rupture commonly observed in both scarred and unscarred uterus in contrast one author reported lower segment rupture in $80 \%$ of cases. ${ }^{26}$ Total maternal mortality was $9.3 \%$ in our study while another study reported $11.43 \% .{ }^{27}$ In our study perinatal mortality was $91.30 \% \%$ while other study reported $78.66 \% .{ }^{15}$ Subtotal hysterectomy done in $10.4 \%$ and $6.8 \%$ cases of unscarred and scarred rupture respectively while another study reported subtotal hysterectomy in $32.1 \%$ cases. $^{13}$

\section{CONCLUSION}

In our study morbidity is high with unscarred rupture as compared to rupture of scarred uterus, more hysterectomies performed in unscarred rupture due to involvement of both segment of uterus and extension of tear to the vaginal fornices. Thus, suggested primary focus is to increase institutional deliveries, proper antenatal care and to avoid unnecessary caesarean section. Early surgical intervention is the main key to achieve good results. In present study perinatal mortality $91.30 \%$ and maternal deaths were $9.37 \%$. Thus, reduction of maternal morbidity, mortality and perinatal mortality possible by preventing rupture of uterus.

\section{ACKNOWLEDGEMENT}

I acknowledge Prof.Vinita Das, Head of the Department, Department of Obst. and Gynaecology for constant support.

\section{CONFLICT OF INTEREST}

The authors declare that there is no conflict of interest.

\section{ABBREVIATIONS}

US+LS: Upper segment + Lower segment; H/O-History of, PRBC: Packed Red Blood Cells.

\section{REFERENCES}

1. Smith JG, Mertz HL, Merrill DC. Identifying risk factors for uterine rupture. Clin Perinatol. 2008;35(1):85-99.

2. Sahin H, Kolusari A, Yildizhan R, Kurdoglu M, Adali E, Kamaci M. Uterine rupture: A twelve- year clinical analysis. J Maternal Fetal Neonatal Med. 2008;21(7):5036.

3. Vanden AT, Beatrice M, James I, Roosmalen JV. Using audits to reduce the incidence of uterine rupture in a Malawian district hospital. Int J Obstetric Genecol. 2009;10(3):289-94.

4. Menihan CA. Uterine rupture in women attempting a vaginal birth following prior cesarean birth. J Perinatol. 1998;18(6 Pt 1):440-3

5. Hawe JA, Olah KS. Posterior uterine rupture in a patient with a lower segment caesarean section scar complicating prostaglandin induction of labor. BJOG Int J Obstet Gynaecol. 1998;104:857-8.

6. Ozdemir I, Yucel N, Yucel O. Rupture of the pregnant uterus: a 9-year review. Arch Gynecol Obstet. 2005;272(3):229-31.

7. Aziz N, Yousfani S. Analysis of uterine rupture at university teaching hospital Pakistan. Pak J Med Sci. 2015;31(4):920-4.

8. Wen SW, Huang L, Liston R, et al. Severe maternal morbidity in Canada, 19912001. Canadian Medical Association Journal. 2005;173(7):759-63.

9. Hofmeyr GJ, Say L, Gulmezoglu AM. WHO Systemic review of maternal mortality and morbidity: The prevalence of Uterine Rupture. BJOG. 2005;112(9):12218.

10. Ezegwui HU, Nwogu-lkojo EE. Trends in uterine rupture in Enugu, Nigeria. J Obstet Gynaecol. 2005;25(3):260-2.

11. Landon MB, Hauth JC, Leveno KJ, et al. Maternal and perinatal outcomes associated with a trial of labor after prior cesarean delivery. $\mathrm{N}$ Engl J Med. 2004;351(25):2581-9.

12. Ofir, Sheiner E, Levy A, Katz M, Mazor M. Uterine rupture: differences between a scarred and an unscarreduterus. American Journal of Obstetrics and Gynecology. 2004;191(2):425-9.

13. Ahmadi S, Nouira M, Bibi M. Uterine rupture of the unscarred uterus. About 28 cases. Gynecol Obstet Fertil. 2003;31(9):713-7.

14. Aggarwal P, Terhase N. Unscarred uterine rupture: a retrospective study. Int J Reprod Contracept Obstet Gynecol. 2015;4(6):1997-9.

15. Rashmi, Radhakrishnan G, Vaid NB, Agarwal N. Rupture uterus- changing Indian scenario. J Indian Med Assoc. 2001;99(11):634-7.

16. Shipp TO, Zelop C, Repke JT, et al. The association of maternal age and symptomatic uterine rupture during a trial of labor after prior cesarean delivery. Obstet Gynecol. 2002;99(4):585-8.

17. Duhan N, Sangwan N, Dahiya K, Sirohiwal D, Paul A. Rupture of the gravid uterus: A review of 92 cases. J Gynecologic Surg. 2011;27(1):17-9.

18. Schrinsky DC, Benson RC. Rupture of the pregnant uterus: a review. Obstet Gynecol Surv. 1978;33(4):217-32.

19. Qazi Q, Akhtar Z, Khan K, Khan AH. Woman Health, Uterus Rupture, Its Complications and Management in Teaching Hospital Bannu, Pakistan. Maedica. 2012;7(1):49-53

20. Kidantou HL, Mwampagatwa I, Roosmalen JV. Uterine rupture. Retrospective analysis of causes, complications and management outcomes at Muhimbili National Hospital in Dar es Salaam, Tanzania. Tanzan J Health Res.2012;14(3):2205 .

21. Fofie C, Baffoe P. A two-year review of uterine rupture in a regional hospital. Ghana Med J. 2010;44(3):98-102.

22. Mishra SK, Maris N, Uprty OK. Uterus repture: Preventable obstetric tragdies? Aust NZJ Obstet Gynacol. 2006;46(6):541-5.

23. Khan S, Parveen Z, Begum S, Alam I. Uterus rupture a review of 34 cases at Ayub Teaching Hospital. Abbothabad. 2003;15(4):50-2.

24. Khan B, Sultana R, Bashir R, Deeba F. A Ten yearn review of emergency peripartum hysterectomy in a tertiary care hospital. J Ayub Med Coll Abbottabad. 2012;24(1):14-7.

25. Shah N, Khan N. Emergency Obstetric Hysterectomy. A review of 69 cases. $R$ Med J 2009:34(1):75-8.

26. Rizwan N, Abbasi RM. Uterine rupture, frequency of cases and fetomaternal outcome. JPMA. 2011;61(4):322.

27. Dwivedi S, Kumar A. Uterine rupture a retrospective analysis of referral cases at a tertiary care centre in Kanpur City. Internat J Reproductive Contracept, Obstetrics and Gynaecol. 2017;4(4):1148-52 